\title{
Pengaruh Gaya Kepemimpinan Kepala Sekolah dan Motivasi Kerja terhadap Kepuasan Kerja Guru pada Sekolah Dasar Negeri 112/1 Perumnas Kecamatan Muara Bulian Kabupaten Batang Hari
}

\author{
Nadiatul Khoiroh \\ STIE Graha Karya Muara Bulian \\ Correspondence email: Nadiatulkhoiroh1988@yahoo.co.id
}

\begin{abstract}
The tiitle of this research is The Influence of Head School Leadership And Work Motivation On Teacher Work Satisfaction In Public Elementary School 112/1 Perumnas Sub-district of Muara Bulian, Batang Hari Regency. Testing is done using multiple linear regression analysis. Hypothesis testing is done by using $t$ test and $F$ test. The magnitude of the effect is known through testing the Path analysis. Based on the discussion it can be concluded that the effect of Leadership (X1) and Motivation (X2) together on Job Satisfaction (Y) is 53.547\%. In the t test, the effect of Leadership (X1) and Motivation (X2) has a partial effect on Job Satisfaction (Y). in the F test, Leadership (X1) and Motivation (X2) has a simultaneous influence on Job Satisfaction $(Y)$.
\end{abstract}

Keyword: leadership style, work motivation, job satisfaction

\section{PENDAHULUAN}

Era globalisasi dunia memberikan pengaruh di berbagai bidang, termasuk pengaruh terhadap perkembangan pendidikan di Indonesia sehingga diperlukan sumber daya manusia (SDM). Seperti yang diamanatkan dalam pembukaan Undang-Undang Dasar Negara Republik Indonesia Tahun 1945 menyatakan bahwa tujuan nasional adalah untuk melindungi segenap bangsa dan seluruh tumpah darah Indonesia dan untuk memajukan kesejahteraan umum, mencerdaskan kehidupan bangsa dan ikut melaksanakan ketertiban dunia berdasarkan kemerdekaan, perdamaian abadi, dan keadilan sosial. Untuk mewujudkan tujuan nasional tersebut, pendidikan merupakan faktor yang sangat menentukan.

Salah satu amanat Undang-Undang Dasar Negara Republik Indonesia Tahun 1945 tersebut kemudian diatur lebih lanjut dalam Undang-Undang Nomor 20 Tahun 2003 tentang Sistem Pendidikan Nasional yang memiliki viasi terwujudnya sistem pendidikan sebagai pranata social yang kuat dan berwibawa untuk memberdayakan semua warga Negara Indonesia berkembang menjadi manusia yang berkualitas sehingga mampu dan proaktif menjawab tantangan zaman yang selalu berubah. Sebagaimana yang teruang dalam buku H.E Mulyasa bahwa:

Sukses tidaknya pendidikan dan pembelajaran disekolah sangat dipengaruhi oleh kemampuan kepala sekolah dalam mengelola setiap komponen sekolah (who is behind the school). Kemampuan kepala sekolah tersebut terutama berkaitan dengan pengetahuan dan pemahaman mereka terhadap manajemen dan kepemimpinan. Manajemen dan kepemimpinan kepala sekolah perlu lebih ditekankan dalam koordinasi, komunikasi, dan supervisi, karena kelemahan dan hambatan pendidikan seringkali bersumber dari kurangnya koordinasi, komunikasi, dan supervise, sehinggga menyebabkan persepsi yang berbeda siantara komponen-komponen pelaksana di lapangan (kepala dinas, pengawas, kepala sekolah, dan guru), serta kurangnya sosialisasi dari kepala sekolah kepada seluruh tenaga kependidikan lainnya.

Membangun sekolah efektif menuntut kepala sekolah seperti seorang pandito atau begawan dalam dunia pewayangan, karena dalam pelaksanaan pendidikan disekolah yang diperlukan bukan saja seorang pemimpin atau kepalan sekolah tetapi seorang begawan. Begawan adalah pendidik yang mulia, berhati suci, dan rela mengorbankan kehidupannya hanya untuk kebaikan dan pengembangan pendidikan yang efektif semata. Guru merupakan salah satu Sumber Daya Manusia yang berada di sekolah. Kinerja guru disekolah mempunyai peran penting dalam pencapaian tujuan sekolah. Masalah kinerja menjadi sorotan berbagai pihak. Kinerja pemerintah akan dirasakan oleh masyarakat dan kinerja guru akan dirasakan oleh masyarakat dan kinerja guru akan dirasakan oleh siswa atau orang tua siswa. Berbagai usaha dilakukan untuk mencapai kinerja yang baik. Tentu perlunya motivasi dari guru itu sendiri maupun dari kepala sekolah sehinngga tujuan pendidikan dapat tercapai secara efektif dan efisien. Sebagaiman yang dijelaskan dalam buku Oemar Hamalik bahwa "Motivasi adalah perubahan energi dalam diri seseorang yang di tandai dengan timbulnya perasaan dan reaksi untuk mencapai tujuan".

Menurut Siagian 2002 yang dikutip dalam M. Yamin (2015) mendefenisikan Motivasi merupakan suatu hal yang sering disinggung di dalam organisasi baik secara terbuka maupun secara terselubung hal ini membuktikan pentingnya motivasi dalam masalah peningkatan kinerja. bahwa motivasi adalah daya dorong yang dimiliki seseorang yang membuatnya mau dan rela untuk bekerja sekuat tenaga dengan mengerahkan segala kemampuan demi keberhasilan organisasi dalam 
mencapai tujuan. Dengan demikian Kepala Sekolah harus mampu Memotivasi seorang guru didalam proses pendidikan, jika seorang guru sudah mendapatkan dorongan dari kepala sekolah maka dorongan dalam diri guru akan timbul dengan sendiri sehingga kerja sama antara kepala sekolah dan guru akan menghasilkan kepuasan kerja bagi kepala sekolah dan guru itu sendiri.

Selain itu, menurut Davi yang dikutip dalam Alex Kurnia Putra (2016) mendefinisikan 'kepuasan kerja sebagai sekumpulan perasaan menyenangkan dan tidak menyenangkan terhadap pekerjaan mereka. Kepuasan kerja dipandang sebagai perasaan senang atau tidak senang yang relatif, yang berbeda dari pemikiran objektif dan keinginan perilaku. Karena perasaan terkait dengan sikap seseorang, maka kepuasan kerja dapat didefinisikan sebagai sikap umum seseorang terhadap pekerjaan dan harapannya pada organisasi tempat ia bekerja".

Motivasi kerja seorang guru dapat bekerja secara profesional jika pada dirinya terdapat motivasi yang tinggi. Guru yang memiliki motivasi tinggi biasanya akan melaksanakan tugasnya dengan penuh semangat dan energik, karena ada motif-motif atau tujuan tertentu yang melatarbelakangi tindakan tersebut. Kepemimpinan Kepala Sekolah adalah Motivator bagi seorang guru.

Kepuasan kerja guru merupakan hasil kerja yang dapat dicapai seseorang atau kelompok orang dalam suatu organisasi ataupun lembaga, untuk mencapai kinerja yang maksimal dibutuhkan faktor-faktor lain yaitu gaya kepemimpinan kepala sekolah dan motivasi kerja guru yang dapat mempengaruhi kepuasan kerja guru.

Dalam pengamatan awal penulis melihat peran kepala sekolah dalam memberikan motivasi. Penulis melihat bahwa ketika rapat kepala sekolah selaku pimpinan atau pemimpin memberikan motivasi bagi para guru dalam memberikan materi pembelajaran. Kepala sekolah memberikan apresiasi bagi para guru yang telah memenuhi kewajibannya dengan baik, sedangkan jika ada guru yang belum memenuhi kewajiban dengan baik, kepala sekolah tidak menyebutkan nama mereka, hanya memberikan saran secara umum saja, kemudian dipanggil menghadap kepala sekolah lalu diberi arahan dengan perkataan yang baik.

Kepala sekolah selaku pemimpin harus mampu bersikap tegas. Hal ini juga ditunjukan oleh Kepala Sekolah SD N 112/1 Perumnas. Misalnya ketika ada guru yang datang terlambat, guru tersebut harus rela menunggu diluar area sekolah karena pagar sekolah pukul 07.15 sudah ditutup, biasanya setiap hari senin siswa melaksanakan upacara, selasa - kamis senam pagi, jum'at melaksanakan yasinan dan sabtu senam pagi, pagar akan dibuka setelah kegiatan siswa selesai dilaksanakan. Kemudian guru tersebut diberi peringatan oleh kepala sekolah dengan memanggil guru yang bersangkutan kedalam ruangan. Hal ini berlaku kepada setiap guru tanpa terkecuali, kemudian didalam rapat kepala sekolah SD N 112/1 Perumnas mengutamakan maksud dan tujuan dari rapat, hanya saja saran dari guru selama rapat langsung ditanggapi oleh kepala sekolah baik itu setuju ataupun tidak setuju, sehingga tidak sedikit guru yang merasa kecewa, padahal persetujuan dan keputusan harus dipertimbangkan bersama.

\section{Tinjauan Pustaka \\ Kepemimpinan}

Kepemimpinan menurut Bass dan Gibbson (1996) kepemimpinan transfornasional adalah membujuk para pengikut untuk bekerja keras dalam mencapai sasaran yang dibuat. Para pemimpin transfornasional akan memeriksa dengan teliti seluruh filosofi, sistem dan budaya organisasi. Untuk melakukan pengukuran terhadap kepemimpinan transpornasional ini, peneliti melihatnya dari beberapa dimensi yang dalam hal ini diterjemahkan dalam bentuk / karakteristik dari kepemimpinan transpornasional itu sendiri.

Bass dan Gibbson (1996) menyatakan bahwa karakteristik kepemimpinan transformasi tersebut meliputi:

1. Karisma

2. Motivasi dan inspirasi

3. Rangsangan intelektual

4. Pertimbangan individu

\section{Motivasi}

Istilah motivasi didefenisikan dalam berbagai cara oleh para ahli. Manulang (2004:12) mengatakan bahwa motivasi kerja tidak lain dari suatu yang menimbulkan dorongan atau semangat kerja. Dalam artian bahwa motivasi kerja tersebut adalah pendorong semangat kerja. Sementara itu, Mitchel (1985) mendefenisikan motivasi sebagai proses psikologis yang menyebabkan kemunculan, arah, kesinambungan dari tindakantindakan sukarela yang terarah pada tujuan.

Indikator motivasi kerja menurut Gibson yang dikutip oleh Deri Emilia (2016) yaitu:

1. Kesempatan untuk berprestasi.

2. Pengakuan dari teman sejawat.

3. Merasa bangga dengan pekerjaan sebagai guru.

4. Tanggung jawab atas pekerjaannya.

5. Pekerjaan itu sendiri.

6. Kesempatan untuk meningkatkan karir.

\section{Kepuasan Kerja}

Kepuasan kerja menurut Edy (2012) adalah keadaan emosional yang menyenangkan atau tidak menyenangkan dimana karyawan memandang pekerjaannya. Kepuasan kerja mencerminkan perasaan seseorang terhadap pekerjaannya. Hal ini nampak pada sikap positif, karyawan terhadap segala sesuatu yang dihadapi dilingkungan kerjanya. Departemen personalia 
atau manajemen harus selalu memonitor kepuasan kerja karena hal ini mempengaruhi sikap, absensi, perputaran tenaga kerja, semangat kerja, keluhan-keluhan dan masalah-masalah vital lainnya.

Celluci dan De Vries (1978) dalam Fuad Mas'ud (2004) merumuskan indikator-indikator kepuasan kerja dalam 5 indikator sebagai berikut:

1. Kepuasan dengan gaji

2. Kepuasan dengan promosi

3. Kepuasan dengan rekan kerja

4. Kepuasan dengan penyelia

5. Kepuasan dengan pekerjaan itu sendiri.

\section{METODE PENELITIAN \\ Lokasi Penelitian}

Adapun objek penelitian dari penelitian ini adalah Sekolah Dasar Negeri 112/I Perumnas Kelurahan Muara Bulian, Kecamatan Muara Bulian, Kabupaten Batang Hari.

\section{Populasi dan Sampel}

Populasi dalam penelitian ini adalah keseluruhan guru yang ada pada SDN 112/I Perumnas Kelurahan Muara Bulian, Kecamatan Muara Bulian yang tercatat yang berjumlah 23 orang.

Untuk menentukan besarnya sampel yang akan dijadikan responden, peneliti mengacu pada pendapat Arikunto (2008). Arikunto dalam melakukan perhitungan ukuran sampel yang diperoleh menyatakan bahwa apabila populasi di bawah 100 maka diambil semuanya untuk dijadikan sampel. Tapi jika populasi di atas 100 maka diambil $10-25 \%$. Dalam hal ini populasi berjumlah 23 orang, maka sampel yang diambil sebesar 23 orang.

\section{Jenis dan Sumber Data}

Data primer adalah data yang diperoleh dengan cara penelitian dilapangan, yaitu data diperoleh dari para guru SDN 112/I Perumnas Kelurahan Muara Bulian, Kecamatan Muara Bulian dengan melakukan penyebaran kuesioner. Data Sekunder adalah data yang diperoleh dengan cara mengadakan penelitian kepustakaan dan dokumen kepegawaian, dokumen kerja, dan dokumen lainnya yang berasal dari SDN 112/I Perumnas Kelurahan Muara Bulian, Kecamatan Muara Bulian.

Data-data yang didapat bersumber dari dalam (internal) SDN 112/I Perumnas Kelurahan Muara Bulian, Kecamatan Muara Bulian, seperti: data para pegawai, dan data lain yang mendukung. Sedangkan data eksternal bersumber dari literatur-literatur yang berkaitan dengan masalah yang diteliti.

\section{Metode Pengumpulan Data}

Dalam memperoleh data, digunakan metode survey yaitu dengan menggunakan perangkat kuesioner terstruktur yang diajukan pada responden. Format kuesioner terdiri dari dua bagian utama, bagian pertama menyangkut pertanyaan-pertanyaan umum mengenai karakteristik pegawai dan bagian kedua berisi pertanyaan masalah pokok penelitian. Item-item pertanyaan diantaranya adalah seperti telah dikemukakan sebelumnya. Pengumpulan data dilakukan dengan pertama-tama meminta kesediaan para responden untuk berpartisipasi dalam penelitian ini, kemudian menyampaikan perangkat kuesioner penelitian untuk diisi oleh responden.

\section{Tehnik Analisis Data}

Dalam menganalisis dan menginterpretasikan data dan informasi dalam penelitian ini, penulis menggunakan pendekatan analisa statistik/verifikatif.

\section{Path Analysis}

Untuk menjawab permasalahan menggunakan analisis jalur (Path Analysis) yang merupakan suatu metode pendekomposisian korelasi ke dalam bagianbagian yang berbeda untuk menginterprestasikan suatu pengaruh/efek. Metode Path Analysis ini juga digunakan untuk menelaah hubungan antara model kausal yang dirumuskan atas dasar pertimbangan teoritis dan pengetahuan tertentu. Hubungan kausal selain didasarkan pada data, juga didasarkan pada pengetahuan, perumusan hipotesis dan analisis logis, sehingga dapat dikatakan Path Analysis ini dapat digunakan untuk menguji seperangkat hipotesis kausal serta untuk menafsirkan hubungan tersebut. Adapun hubungan struktural antar variabel motivasi dan kepuasan kerja terhadap kinerja dapat dijelaskan pada gambar dibawah ini:

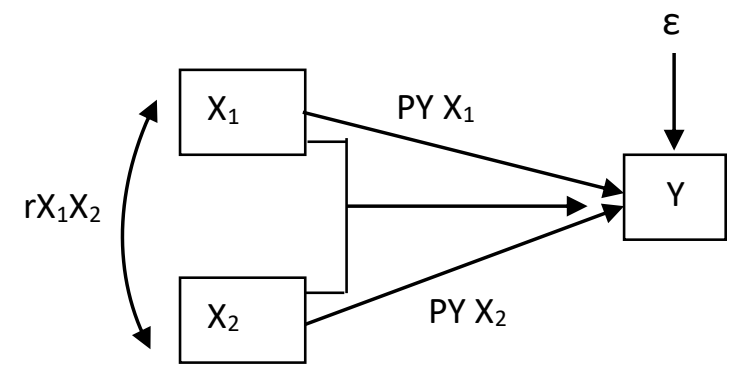

Gambar 1. Hubungan Struktural Antara $\mathrm{X}_{1}$ dan $\mathrm{X}_{2}$ Terhadap Y

Keterangan :

$\mathrm{X}_{1} \quad$ : Kepemimpinan Kepala Sekolah

$\mathrm{X}_{2} \quad$ : Motivasi

Y : Kepuasan Kerja

$\mathrm{P}_{\mathrm{YX} 1}$ dan $\mathrm{P}_{\mathrm{YX} 2}$ adalah koefisien jalur dan $\mathrm{r}_{\mathrm{X} 1 \mathrm{X} 2}$ adalah koefisien korelasi, maka persamaan struktural untuk diagram jalur diatas dinyatakan dengan :

$\mathbf{Y}=\mathbf{P}_{\mathbf{Y X} 1} \mathbf{X}_{1}+\mathbf{P}_{\mathbf{Y X} 2} \mathbf{X}_{2}+\varepsilon$ 
Sedangkan pengaruh antar variabel diatas dinyatakan dengan persamaan sebagai berikut:

Pengaruh X1 terhadap Y:

1. Pengaruh langsung $: \mathrm{X}_{1} \rightarrow \mathrm{Y}=\left(\mathrm{P}_{\mathrm{YX} 1}\right) \mathrm{x}\left(\mathrm{P}_{\mathrm{YX} 1}\right)$

2. Pengaruh tidak langsung: $\mathrm{X}_{1} \Omega \mathrm{X}_{2} \rightarrow \mathrm{Y}=\left(\mathrm{P}_{\mathrm{YX} 1)} \mathrm{X}\right.$ ( $\mathrm{r}_{\mathrm{X} 1 \mathrm{X} 2)} \mathrm{x}\left(\mathrm{P}_{\mathrm{YX} 2)}\right.$

Pengaruh total : pengaruh langsung + pengaruh tidak langsung

Pengaruh X2 terhadap Y:

1. Pengaruh langsung $: \mathrm{X}_{2} \rightarrow \mathrm{Y}=\left(\mathrm{P}_{\mathrm{YX} 2}\right) \mathrm{x}\left(\mathrm{P}_{\mathrm{YX} 2}\right)$

2. Pengaruh tidak langsung: $\mathrm{X}_{2} \Omega^{\prime} \mathrm{X}_{1} \rightarrow \mathrm{Y}=\left(\mathrm{P}_{\mathrm{YX} 2)} \mathrm{X}\right.$ $\left(\mathrm{r}_{\mathrm{X} 1 \mathrm{X} 2)} \mathrm{x}\left(\mathrm{P}_{\mathrm{YX} 1)}\right.\right.$

Pengaruh total : pengaruh langsung + pengaruh tidak langsung

3. $\mathrm{Y}=\mathrm{P}_{\mathrm{yx} 1}+\mathrm{P}_{\mathrm{yx} 2}+\varepsilon_{1}$

\section{Uji t}

Uji t digunkan untuk mengkaji koefisien regresi secara individual yaitu antara variabel independen dengan variabel dependen. Adapun langkah-langkahnya sebagai berikut:

1. Menentukan Hipotesis

$\mathrm{HO}: \mathrm{bi}=0$, (Tidak ada pengaruh yang signifikan antara variabel independen $(\mathrm{x})$ terhadap variabel dependent (y))
H1 : bi $\neq 0$,(Ada pengaruh yang signifikan antara variabel independen $(\mathrm{x})$ terhadap variabel dependen (y) )

2. Menentukan tingkat signifikansi

Diuji dengan tingkat signifikansi (a) sebesar 0.05.

3. Kesimpulan

H0 diterima apabila $-\mathrm{t}$ tabel $<\mathrm{t}$ hitung $<\mathrm{t}$ tabel

H0 di tolak apabila thitung $>\mathrm{t}$ tabel atau $\mathrm{t}$ hitung $<-$ $\mathrm{t}$ tabel.

\section{Uji F}

Uji ini digunakan untuk mengetahui apakah seluruh variabel bebas secara simultan mempunyai pengaruh yang bermakna terhadap variabel terikatnya. Pengujian dilakukan dengan membandingkan nilai $\mathrm{F}_{\text {hitung }}$ dengan $\mathrm{F}_{\text {table }}$ pada derajat kesalahan $5 \%$. Apabila nilai $F_{\text {hitung }}>$ dari nilai $F_{\text {table, }}$, berarti bahwa variabel bebasnya secara simultan memberikan pengaruh yang bermakna terhadap variabel tergantungnya.

\section{HASIL DAN PEMBAHASAN \\ Analisis Jalur Pengaruh kepemimpinan dan Motivasi terhadap Kepuasan Kerja}

Dalam analisis ini, diperlukan nilai koefisien jalur baik jalur kepemimpinan terhadap kepuasan kerja, maupun jalur motivasi terhadap kepuasan kerja. Berikut koefisien keseluruhan jalur dalam penelitian ini :

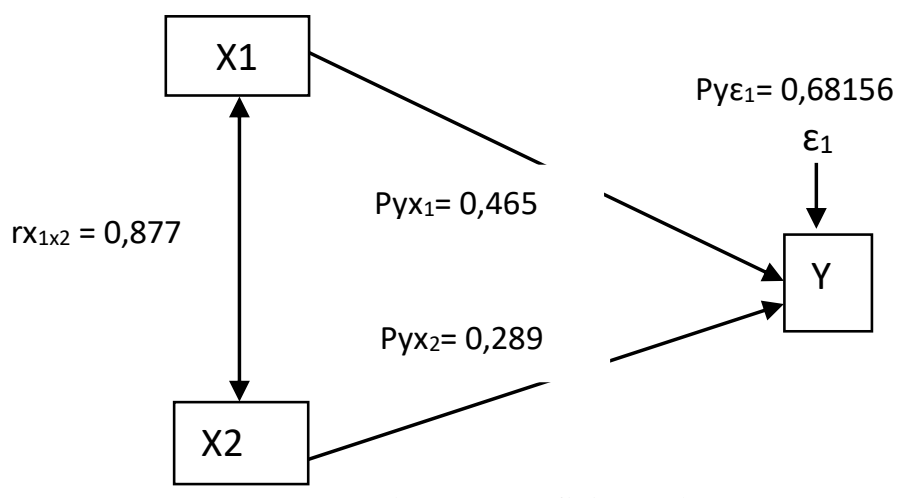

Gambar 2. Koefisien Jalur

Pengaruh langsung Kepemimpinan $\left(\mathrm{X}_{1}\right)$ terhadap

Kepuasan Kerja (Y):

$$
\begin{aligned}
\mathrm{X}_{1} \longrightarrow \mathrm{Y} & =\left(\mathrm{pYX}_{1}\right)\left(\mathrm{pYX}_{1}\right) \\
& =0,465 \times 0,465 \\
& =0,21623 \\
& =21,623 \%
\end{aligned}
$$

Pengaruh tidak langsung Kepemimpinan $\left(\mathrm{X}_{1}\right)$ terhadap Kepuasan Kerja (Y) melalui Motivasi $\left(\mathrm{X}_{2}\right)$ :

$$
\begin{aligned}
\mathrm{X}_{1} \longrightarrow \mathrm{Y} \quad \mathrm{X}_{2} & =\left(\mathrm{pYX} \mathrm{X}_{1}\right)\left(\mathrm{rx}_{1} \mathrm{X}_{2}\right)(\mathrm{pYX} 2) \\
& =0,465 \times 0,877 \times 0,289 \\
& =0,11786 \\
& =11,786 \%
\end{aligned}
$$

Total pengaruh langsung dan tidak langsung Kepemimpinan $\left(\mathrm{X}_{1}\right)$ terhadap Kepuasan Kerja $(\mathrm{Y})$ :

$$
\begin{aligned}
& =0,21623+0,11786 \\
& =0,33409 \\
& =33,409 \%
\end{aligned}
$$

Dari rincian diatas pengaruh Kepemimpinan $\left(\mathrm{X}_{1}\right)$ terhadap Kepuasan Kerja (Y) sebesar 33,409\%. Pengaruh langsung Motivasi $\left(\mathrm{X}_{2}\right)$ terhadap Kepuasan Kerja (Y):

$$
\begin{aligned}
\mathrm{X}_{2} \longrightarrow \mathrm{Y} & =\left(\mathrm{pYX}_{2}\right)\left(\mathrm{pYX}_{2}\right) \\
& =0,289 \times 0,289 \\
& =0,08352 \\
& =8,352 \%
\end{aligned}
$$

Pengaruh tidak langsung Motivasi $\left(\mathrm{X}_{2}\right)$ terhadap Kepuasan Kerja (Y) melalui Kepemimpinan $\left(\mathrm{X}_{1}\right)$ : $\mathrm{X}_{2} \longrightarrow \mathrm{Y} \Omega \mathrm{X}_{1}=\left(\mathrm{pYX}_{2}\right)\left(\mathrm{rX}_{2} \mathrm{X}_{1}\right)\left(\mathrm{pYX}_{1}\right)$ 


$$
\begin{aligned}
& =0,289 \times 0,877 \times 0,465 \\
& =0,11786 \\
& =11,786 \%
\end{aligned}
$$

Total pengaruh langsung dan tidak langsung Motivasi $\left(\mathrm{X}_{2}\right)$ terhadap Kepuasan Kerja (Y):

$$
\begin{aligned}
& =0,08352+0,11786 \\
& =0,20138 \\
& =20,138 \%
\end{aligned}
$$

Dari rincian diatas pengaruh Motivasi $\left(\mathrm{X}_{2}\right)$ terhadap Kepuasan Kerja (Y) sebesar 20,138\%.

Pengaruh Kepemimpinan (X1) dan Motivasi $\left(X_{2}\right)$ secara bersama-sama terhadap Kepuasan Kerja (Y)

Pengaruh langsung Kepemimpinan (X1) dan Motivasi $\left(\mathrm{X}_{2}\right)$ secara bersama-sama terhadap $\operatorname{Kepuasan} \operatorname{Kerja}(\mathrm{Y})$

$=\left(\mathrm{pYX}_{1}\right)\left(\mathrm{pYX}_{1}\right)+\left(\mathrm{pYX}_{2}\right)\left(\mathrm{pYX}_{2}\right)$

$=(0,465 \times 0,465)+(0,289 \times 0,289)$

$=0,21623+0,8352$

$=0,29975=29,975 \%$

Pengaruh tidak langsung Kepemimpinan (X1) dan

Motivasi $\left(\mathrm{X}_{2}\right)$ secara bersama-sama terhadap Kepuasan

$\operatorname{Kerja}(\mathrm{Y})$ :

$=\left(\mathrm{pYX}_{1}\right)\left(\mathrm{rx}_{2} \mathrm{x}_{1}\right)\left(\mathrm{pYX} \mathrm{X}_{2}\right)+\left(\mathrm{pYX} \mathrm{X}_{2}\right)\left(\mathrm{rx}_{2} \mathrm{x}_{1}\right)\left(\mathrm{pYX}_{1}\right)$

$=(0,465 \times 0,877 \times 0,289)+(0,289 \times 0,877 \times 0,465)$

$=0,11786+0,11786$

$=0,23572=23,572 \%$

Total pengaruh Kepemimpinan (X1) dan Motivasi $\left(\mathrm{X}_{2}\right)$ secara bersama-sama terhadap Kepuasan Kerja (Y) :

$=0,29975+0,23572$

$=0,53547$

$=53,547 \%$

Dari rincian diatas pengaruh Kepemimpinan (X1) dan Motivasi $\left(\mathrm{X}_{2}\right)$ secara bersama-sama terhadap Kepuasan Kerja (Y) sebesar 53,547\%.

Variabel Residu

$$
\begin{aligned}
\operatorname{Py}_{1} & =\sqrt{ } 1-\mathrm{R}^{2} \mathrm{Y}\left(\mathrm{X}_{1}, \mathrm{X}_{2}\right) \\
& =\sqrt{1-0,53547} \\
& =0,68156
\end{aligned}
$$

Jadi persamaan struktur adalah sebagai berikut:

$$
\begin{aligned}
\mathrm{Y} & =\mathrm{Pyx}_{1} \mathrm{X} 1+\mathrm{Pyx}_{2} \mathrm{X} 2+\varepsilon_{1} \\
& =0,465 \mathrm{X} 1+0,289 \mathrm{X} 2+0,68156
\end{aligned}
$$

\section{Pengujian Hipotesis}

Pengaruh kepemimpinan terhadap kepuasan kerja yang ada membuktikan bahwa motivasi terhadap kinerja jika dilihat dari nilai t hitung yaitu sebesar 2,258 dimana nilai t tabel pada derajat kesalahan $5 \%$. sebesar 1,72074 dan tingkat signifikan sebesar 0,013 berarti variabel kepemimpinan memberikan pengaruh secara parsial dan signifikan terhadap variabel kepuasan kerja.
Selanjutnya, pengaruh motivasi terhadap kepuasan kerja yang ada membuktikan bahwa motivasi terhadap kepuasan kerja jika dilihat dari nilai t hitung yaitu sebesar 1,833 dimana nilai t tabel pada derajat kesalahan $5 \%$. sebesar 1,72074 dan tingkat signifikan sebesar 0,027 berarti variabel motivasi memberi pengaruh secara parsial dan signifikan terhadap variabel kepuasan kerja.

Selanjutnya, jika dilihat dari nilai $\mathrm{F}$ hitung yaitu sebesar 7,892 dimana nilai $\mathrm{F}$ tabel dengan derajat kesalahan 5\% sebesar 4,35 berarti variabel kepemimpinan dan motivasi mempengaruhi variabel kepuasan kerja secara bersama-sama dan signifikan.

\section{SIMPULAN}

Berdasarkan pada pembahasan dapat ditarik kesimpulan bahwa pengaruh Kepemimpinan (X1) dan Motivasi $\left(\mathrm{X}_{2}\right)$ secara bersama-sama terhadap Kepuasan Kerja (Y) sebesar 53,547\%. Pada uji t, pengaruh Kepemimpinan (X1) dan Motivasi $\left(\mathrm{X}_{2}\right)$ memiliki pengaruh secara parsial terhadap Kepuasan Kerja (Y). pada uji F, Kepemimpinan (X1) dan Motivasi $\left(\mathrm{X}_{2}\right)$ memiliki pengaruh secara simultan terhadap Kepuasan $\operatorname{Kerja}(Y)$.

\section{DAFTAR PUSTAKA}

Alex Kurnia Putra, Pengaruh Komitmen Kerja dan Quality Of Work Life (QWL Terhadap Kepuasan Kerja dan Dampaknya Terhadap Kinerja Karyawan PT. Indofood Cabang Jambi, Tesis Magister Manajemen Universitas Batanghari Jambi, 2016.

Bass, B.M. 1996. A New Paradigm of Leadershhip: An Inquiry Into Transformal Leadership. Alexandria, VA: U.S. Army Research Institute for Behavioral and Social Sciences.

Budi Darma, Pengaruh Fasilitas Kerja dan Kompetensi terhadap Kepuasan Kerja Pegawai dan Dampaknya terhadap Kinerja Pegawai Kantor Kelurahan Sekecamatan Muara Bulian Kabupaten Batang Hari. Tesis Magister Manajemen Universitas Batanghari Jambi, 2016.

Cholid Narbuko dan Abu Achmadi, Metodologi penelitian. Jakarta: PT Bumi Aksara, 2010.

Danang Sunyoto, Perilaku Organisasional. Yokyakarta: CAPS, 2013.

Dearlina Sinaga, "Pegaruh Motivasi Berprestasi, Kepuasan Keja, dan Komitmen Kerja Terhadap KinerjaPimpinan pada Universitas Swasta di Medan", Disertasi. Jakarta: PPS Universitas Negeri Jakarta, 2008.

Deri Emilia, Pengaruh Gaya Kepemimpinan Kepala Sekolah dan Disiplin Terhadap Kinerja Guru Melalui Motivasi Pada SMK Negeri 1 Sarolangun, Tesis Magister Manajemen Universitas Batanghari, 2016.

Edy Sutrisno, Manajemen Sumber Daya Manusia. 
Jakarta: Prenamedia Group, 2012.

E.Mulyasa, Menjadi Kepala Sekolah Profesional Dalam Konteks Menyukseskan MBS dan KBK. Bandung: PT Remaja Rosdakarya, 2008.

Gibson, James L., Ivancevich, John M., Donnelly, James H. Jr. 1996. Organisasi: Perilaku Struktur, Proses, Edisi Kedelapan. Tangerang: Binarupa Aksara.

Iskandar, Metodologi Penelitian Pendidikan dan Sosial (Jakarta: Gaung Persada Press, 2009), hal. 66

Kartono Agustiyanto, Pengaruh Lingkungan Kerja DAN Motivasi Terhadap Kepuasan Kerja Dan Dampaknya Terhadap Kinerja Pegawai Pada Kantor Pertahanan Kabupaten merangin, Tesis Magister Fakultas Ekonomi Universitas Batanghari Jambi, 2018.

Made Pidarta, sepervisi pendidikan Kontekstual. Jakarta : PT Renika Cipta, 2009.

Manulang, M. 2004. Manajemen Personalia. Cetakan kedua. Yogyakarta: Gajah Mada University Press.

Mitchel Terrence R, 1985, Poeple in Organization. Mc Grow Hill Book Co, Singapore

Muhammad, Metodologi Penelitian Ekonomi Islam. Jakarta: PT Raja Grafindo Persada, 2008

Mukhtar, Bimbingan Skripsi, Tesis, dan Artikel Ilmiah. Jakarta: Gaung Persada Press, 2010.

M.Yamin, Pengaruh Disiplin dan Pelatihan Melalui Motivasi Terhadap Kinerja Pegawai Pada Satuan Polisi Pamong Praja Kabupaten Tanjung Jabung Barat, Tesis Magister Manajemen Universitas Batanghari Jambi, 2015.

Ngalim Purwanto, Psikologi pendidikan. Bandung: PT Remaja Rosdakarya, 2011.

Oemar Hamalik, Manajemen Pelatihan Ketenagakerjaan. Jakarta : PT Bumi Aksara, 2007.

Prim Masrokan Mutohar, Manajemen Mutu Sekolah. Jogjakarta: Ar-Ruzz Media, 2013.

Rusman, Manajemen Kurikulum. Jakarta : PT Raja Grafindo Persada, 2011.

Sambas Ali Mihidin dan Maman Abdurahman, Analisis Korelasi, Regresi dan Jalur dalam Penelitian. Bandung: CV Pustaka Setia, 2008.

Siti Rochana, "Pengaruh Iklim Organisasi, Reward dan Kepuasan Kerja Terhadap Motivasi Kerja", Disertasi. Jakarta: PPS Universitas Negeri Jakarta, 2008.

Sugiyono, Metode Penelitian Kuantitatif Kualitatif dan $R \& D$. Bandung: Alfabeta, 2009..

Suharsimi Arikunto, Prosedur Penelitian Suatu Pendekatan Praktik. Jakarta: PT Rineka Cipta 2008.

Sukardi, Metodologi Penelitian Pendidikan. Jakarta: PT Bumi Aksara, 2011.

Suryadi, Manajememen Kepala Kekolah Dalam Meningkatkan Kualitas Guru Bimbingan
Konseling, Skripsi Sarjana Strata 1 Mahasiswa STAI Muara Bulian, 2009.

Syafaruddin, Kepemimpinan Pendidikan Jakarta : PT. Ciputat Press, 2010.

Syaiful Bahri Djamarah, Psikologi Belajar. Jakarta: PT Rineka Cipta, 2008.

Syahrizal Abbas, Manajemen Perguruaan Tinggi. Jakarta: PT Fajar Interpratama Offset, 2009.

Veithzal Rivai dan Arvian, Islamic Leadership. Jakarta: Bumi Aksara, 2009.

Wahjosumidjo, Kepemimpinan Kepala Sekolah. Jakarta: PT Rajagrafindo Persada, 2010 